\title{
Mothers, Daughters and Fear of Crime
}

\author{
By Sevgi Çoban*
}

This study focuses on the relationship of gender norms and the fear of crime within mother-daughter interactions. Within this scope, 21 mother-daughter couples were interviewed. Semi-structured and in-depth interview techniques were adopted to examine interviewees' perceptions on crime and their fear management tactics. Fear for a loved one generates oppressive dynamics on women's lives. These dynamics result in severe restrictions in their mobility, their daily mobility in time and place, their femininity and self-autonomy.

Keywords: fear of crime, gender, mother-daughter relationships.

\section{Introduction}

This study focuses on gender and fear of crime in mother-daughter relationships. It examines mothers' and daughters' fear of crime and how these restrictions are made, sensed and experienced by mothers and daughters in their shared experiences.

\section{Literature Review}

Literature on gendered fear of crime indicates that crime is a deeply gendered phenomenon. From their early ages, women not only learn how to avoid crime, but also transform it into a lifestyle by acting and dressing properly, avoiding risky places and times, having an edge on men etc. These are all acquired by socialization. Based on my observations on mother-daughter interactions in Turkish families as well as my experiences, I suggest that fear of crime is culturally and relationally produced: Through daily interactions, mothers and daughters share their strategies against crime risks which affect their mobility.

Women's fear of crime is described to be the fear of sexual crimes (Ferraro 1996, Fisher and Sloan 2003, Warr 1984). In relation to this, research indicates that sexual assault has a substantial effect on women's fear of crime (Ferraro 1996, Fisher and Sloan 2003, May 2001, Stanko 1996, Wilcox et al. 2006). A part of research further suggests that the primary reason of fear of crime is fear of sexual assault (Ferarro 1996, Fisher and Sloan 2003, May 2001, Wilcox et al. 2006).

It is indicated by the fear of crime literature that fear has a strong effect on women's lives. According to Stanko (1995: 51) "as a consequence of fear, women watch out themselves by restricting their activities in public due to the anxiety about potential violence and by using, in public and in private, more safety precautions than do men". Those above restrictions are particularly spatial ones.

*Assistant Professor, Hacettepe University, Turkey. 
Valentine (1989: 386) states that the predominant strategy women adopt is "the avoidance of perceived 'dangerous places' at 'dangerous times'". This point brings together with it the argument that fear of crime is a control strategy which oppress women (Rader and Haynes 2011, Gardner 1990, Hollander 2001, Madriz 1997, Stanko 1996, Van Eijk 2017).

The overwhelming majority of studies focusing on fear of crime and gender have been conducted in Western societies. These investigations have revealed the importance of the cultural context of the fear of crime. It is important to understand how the fear of crime is shaped on a gender basis in different cultural contexts.

Turkey is culturally different from Western societies in certain respects. One of the most important differences in the context of the fear of crime is the pressure created by patriarchal social norms on women, which is a combination of Islam and traditional values.

Kandiyoti (1991: 26) indicates that in classical patriarchy, the women of landed households are ideally released from agricultural work and confined to domesticity, often secluded as a symbol of prestige and family honour. They increasingly come to depend on men for both economic support and symbolic shelter".

As Kandiyoti (1988) and Kağıtçıbaşı (1970) pointed out, the Turkish family relies not on the mutual independence of members in the modernization process, but on an intense mutual emotional dependency, on the contrary. This point is particularly important in focusing on mother-daughter relationships, because this emotional dependence means that women are supported and supervised by the family as much as they get married, and especially close to each other's daily relationship with the mother.

As it is argued by Day (2000: 116), ethics of care extends women's fear to encompass apprehension for children and others; fear for others must be considered as an important part of gendered fear of crime. However, fear for important others are a relatively neglected subject in the literature. This study draws attention to this dimension of having a feeling of concern among loved ones, through mother and daughter relationships.

There are studies that scrutinize fear of crime in relational models such as wife-husband relationships (Rader 2008, Rader, 2010). However, mother and daughter relationships are considered to produce different dynamics on fear of crime due to different nature of the relationship in a different cultural context. The aim of this study is to shed light on these aspects of fear of crime and the results that generates in connection with patriarchy.

\section{Method}

Semi-structured and in-depth interviews have been conducted with mothers and their daughters from July 2016 to January 2017. Interviews were lasted 47 to 92 minutes. Snowball sampling was used to find the interviewees. Initially, graduate university students were informed that mothers and their single daughters 
were sought as participants in the study. 21 couples were found appropriate for the research and consented to participate in the interviews. Since the participation was voluntary and interviewees were not paid, the number of participants was limited to 21 couples. The sample is not representative of the general population of Turkey. A tape recorder was used to record all interviews.

\section{Mothers and Daughters}

Mothers' age range starts from 40 up to 56. Those mothers, who were not residing in Ankara, were reached through their daughters. They were interviewed during their visit to Ankara. Others who do not come to Ankara were interviewed online. Not many of them have a professional job, and first generation's jobs are given with their numbers as follows; 5 of them do unpaid housework in their own houses, 2 retired and 2 active civil servants. Among mothers, there are also 2 of the who engaged in farm work, 2 shop keeping, 2 domestic worker, 1 babysitter, 1 primary school teacher, 1 nursery school teacher, private school teacher and one and animal rights activist. Majority of them are primary school graduates but there are also high school, college and university graduates. Two of them are divorced and one is a widower, the rest are married and live together with their husbands. Sixteen mothers live in Ankara while five of them live in another city.

As for daughters, their ages range starts from 18 up to 28 years old. Sixteen of them attend university; one works and attends university at the same time. Others do temporary jobs such as booth attendance, waitressing or sales assistance. They live with their parents. Daughters whose parents live in another city also return to their parents' houses at the end of the school year. Participants from this second generation were chosen among unmarried women because marriage was thought to change mother-daughter relationships regarding fear of crime. Face to face interviews were made with daughters. There is one walking disabled and one visually handicapped participant in the sample.

\section{Results}

Interviews reveal themes on the meaning of fear of crime for women according to temporal and spatial dimensions, its connection to the fear of being marginalized by the society and the fear management tactics.

\section{Fear of Crime}

Fear of crime means fear of sexual assault for women. Almost all of the participants say they are afraid of sexual crimes, especially rape. Conversations about why they fear this most and not any other violent crime revealed two subthemes: First is the patriarchal code of honor. According to this traditional norm, honor is related to sexual purity of the female body. Not only women are responsible to protect their "purity" but also men are responsible to protect women's "purity" within their family. Thus, any kind of sexual attempt directed to 
women is considered as a treat to "honor". This generates two results. Fist, because honor is explained over women, it is perceived that it is women's duty to keep safe, protect herself from sexual risks. Thus, in some cases of sexual crimes women are blamed for acting careless or "inviting" risks. For example, being out alone late at night can be considered as a dishonorable behavior. Secondly, because men's honor is based on sexual purity of his female relatives; men traditionally have a patriarchal authority over their female relatives.

Honor is critical in understanding women's fear of crime. Because honor is a central traditional value, women perceive any kind of sexual assault as an "unrecoverable loss". Thus most of the women are afraid of sexual crimes more than they are of other types of crimes. Rüveyde's words demonstrate that she perceives sexual crimes as an attack against her honor. She sees a potential sexual attack as an "unrecoverable loss":

Rüveyde (47 years old) describes this as such: "I mean, it is our honor... First you protect that; and body may heal; but this, honor, doesn't heal".

The majority of the women state that they are afraid of crimes not for themselves but for their daughters. While daughters are far more critical to this perception, they admit and accept its social power. Rüveyde's daughter Rabia (22 years old) for instance states feeling guilty though she finds her mother narrowminded about gender issues and objects about her many times: "Without the car, I don't go out of the house when I wear a skirt. I don't go around by walking, not in my life! Everybody stares at me; they turn it into a matter of honor at that moment. Like 'Hey, over there, she wore a skirt, she must have gone to the bad.' So I feel guilty for my personality."

The second subtheme manifests itself at this point: Women are well aware that sexual crimes bring them risks of marginalization by the society. For instance Dilara (22 years old) indicates: "It is the victim who is to blame, not the rapist. Because she is considered like 'She should have protected her honor.', 'What was she doing outside at that hour? ' Society judges women."

It is observed that mothers and daughters usually have similar perceptions on sexual crime-honor connection yet when the mother comes from a country origin on the contrary the daughter was grown up in a big city, differences may arise. Dilara's mother, Kamuran (40 years old) exemplifies this when she interprets the recent news about a woman who was raped in a public bus by the driver at night in Ankara City: "A lady who is a teacher got raped, she was raped. We argued on that with my husband, [I said] 'What was she doing there at that hour?"

The second type of fear of crime which affects women's lives is bombing attacks which escalated between 2011 and 2016 and caused panic in Turkey. Women's statements indicate that fear of those attacks combine with fear of sexual assault as Damla (26 years old) states "In crowded places, there is that risk of bombing and in isolated places there are risks of being kidnapped, [and] rape." In this respect, nonsexual crimes said to be perceived by women in a different way than men due to their perceived articulation to sexual risks. 


\section{Temporality and Spatiality of Fear of Crime}

As can be seen from the perceptions on bombing, crime draws lines on time and space on women's lives. For instance, Ümmü (21 years old) speaks of the line between day and night: "What we fear most at night is rape, as I mentioned and there is the perception of 'What is a woman supposed to do outside at midnight'; and I especially fear this. But in the daytime, if I am in Kızllay ${ }^{1}$, I fear bombs the most". The combination of fear of nonsexual and sexual crimes broadens these spatial and temporal lines. In extreme, women are entrapped inside them.

Two subthemes come to light on spatiality: (1) Women's interrupted mobility due to the sexual harassment they are likely to encounter in public transport, taxi and on hitchhiking and (2) the spatial effect of traditional neighborhood relations on women's fear.

First, multitude of current news on violent crimes against women in public transport vehicles which created a moral panic has a critical role on spatial interruption of women's lives. One of the news is about a 20 year old university student young woman who was murdered after an attempted rape by the driver of the bus she had got on in a southern city of Turkey in 2015. Feryal (51 years old): "That incident in Mersin... I have read about the girl only yesterday. There is a park close to our home which was given her name. It affected me a lot. Glad that you remind me. I tell my daughters 'Don't you ever get on deadheading busses.'"

One of the most controversial issues between mothers and daughters is hitchhiking. Nesrin and Seçil is a typical example. Nesrin (47 years old) puts this:

"What I fear most, such, what can I say, can be kidnapping. Because I have heard that they hitchhike at school, and she [Seçil] gets on, I fear this most. She can be kidnapped, raped. This is my biggest fear. I protest but she doesn't listen."

Her daughter, Seçil (21 years old), on the other hand, mentioned hitchhiking before having a car and reflects the social norms on hitchhiking:

Seçil (21 years old): "People who don't know hitchhiking culture always have prejudice and criticise hitchiking. 'Why would they hitchhike anyway?' they exclaimed. I have heard about a lot of comments [written on social media] like 'They should bear the consequences if they do this'".

Mothers object to their daughter's hitchhiking not just because it is risky. The risk perception is strictly connected to gender roles. Thus, women's hitchhiking is "disapproved" (Nesrin, 47 years old) or considered to be "shameful" (Rüveyde, 47 years old). Some women from second generation with high spatial mobility on the other hand, consider hitchhiking as a part of their lifestyle. This differentiation is partly a result of the new requirements of new lifestyles such as higher mobility for educational purposes.

For a visually handicapped woman fear makes travelling much more

\footnotetext{
${ }^{1}$ Kizılay is one of the most crowded centers of Ankara.
} 
challenging. For instance, Ümmü (21 years old) recalls news about a woman passenger travelling intercity bus sitting on an aisle seat who was harassed by the bus host: "When I sit on the aisle side [in the bus], this pops to my mind that; I am going to sleep and then I am afraid to. I say 'I better not sleep." She tells when she doesn't prefer traveling on her own. If she has no other options she does not even get off the bus at the bus stops. She narrates the difficulties she has at five and half an hour bus travel between Mersin and Ankara cities: "If I ask his [the bus host's] help to go to the restroom or for anything else, or if I get hungry and want to have some food at the stop, he [bus host] can take me to somewhere else."

Neighborhood as a second subtheme is another important spatial breaking point on women's mobility. Neighborhood brings safety with traditional relationships: Neslihan (19 years old) "The town I live in is much safer [than Ankara] to me because, we [her family] sometimes don't lock the door there. Sometimes, our belongings are left outside. There seems much safer because we got no harm there."

Gülçin (47 years old) indicates division of safety work in the neighborhood in the past:

"When we got on the bus with [male] friends from the neighborhood they used to circle around us [girls], we stood in the middle. They used to protect us because they assume us as their sisters."

As a safe place, neighborhood is also a place of informal social control, on the other hand. Neighborhood relationships provide security to the residents but at the same time put the burden of being honorable on women's shoulders. This is obvious in Gülçin's (43 years old) story. She tells that when she was 20 or 21 year old, she used to work in a textile factory until late at night. One night when she got off the bus and was walking home she was attacked by a man. She narrates:

"He tried to pull me down. Was he going to get me in a car or what? But I didn't even hear his footsteps, he was that quiet. I am struggling, trying to scream but I can't. I wanted to scream. Then what occurred to me: I didn't want to scream. Well, it's neighborhood. You know old neighborhoods; they are a bit gossipy. So, if I scream- I am a young girl-, I am going to get a bad reputation. I thought that."

In addition of space, time creates (1) differentiation of life style in daytime and night time and (2) on a longer perceptions contrast on whether Turkey is becoming a more secure or insecure place for women by time.

For mothers being out at night is a reason to afraid for their daughters. They restrict their daughters' lives especially in terms of going out after sunset, apart from necessary situations such as going out for matriculation courses. These long term restrictions have critical effects on taking shape of daughters' lifestyles. Seçil (21 years old) says that "She [Her mother] says 'Don't go out. If you have to, go early; why so late? Get things done in the daytime"" She indicates they rarely have a disagreement: "I usually don't have a need to [go out at night]." 
Few daughters talk about going to the movies or going out with friends at night. However, like Seçil, many of them reveal that they organized their lives according to this restriction. Thus, narratives come to a typical end such as "I can be out at night if I want to, but I don't".

Strikingly, mothers who defend the gender equality make strict restrictions as well. Yet, they admit to have contradiction with themselves: For instance Seçil's mother Nesrin (47 years old) explains: "In the end, I feel guilty. I blame myself for behaving permissively where I shouldn't. But I want my children to not miss anything, learn to protect themselves, learn the life outside our home; I wish for it. So, I contradict myself."

A second temporal line is drawn between past and present society. Women think that society became more dangerous and violent especially against women. Women from both generations highlight that: Dilara (22 years old): "In the nineties, I lived my childhood on the streets but now people can't let their children on streets. There is either the fear of kidnapping or getting them missed."

Women from both generations feel the pressure of this but mothers take this as a systematic change in connection with the rise of political neo-conservatism. Feryal (51 years old) put it this way:

"We used to live in Elvankent ${ }^{2}$. It is very close to Sincan ${ }^{3}$ and it had also changes. Pressure against women got intensified. Such that it is not ten at night, even at nine it is impossible to go and walk in the park. There are many bummers and they are in the park all the time. They harass you."

Deniz (54 years old) "When I lived in Anittepe, I used to be the kind of person who returns home at eleven or twelve at night. See, even, I used to walk home from Kizılay to my home, yet I started to take taxis for short distances."

Women who have more conservative inclinations explain this change with the dissolution of the traditional "neighborhood". Women who take the gender equality stand on the other hand, see this change as a reflection of patriarchal power relations sharpened by the political power in Turkey.

\section{Limitations}

This study focuses only on the interactions between mothers and daughters. However, to develop a more comprehensive view on how fear of crime is generated within family dynamics, fathers' attitudes on the issue as well as fatherdaughter interactions are no less important. A further study may fill this gap.

\footnotetext{
${ }^{2}$ A housing district in eastern part of Ankara.

${ }^{3} \mathrm{~A}$ metropolitan district located in eastern part of Ankara, near Elvankent District.
} 


\section{Conclusion}

This study shed light on how the fear of crime takes shape on the gender basis, how it is reproduced by intergenerational relationships and how it is articulated to patriarchy within this reproduction. In the light of it, this study suggests a new perspective on fear of crime: Fear of crime felt for loved ones as a social control mechanism.

There are studies on the issue on how fear of crime operates in the relationships of couples (Rader 2009) or in the socialization process (Rader and Haynes 2011). This research on the other hand, focuses on the relationship of mothers and daughters. Fear of crime, in this sense, manifests itself as a mindset that provides women with specific knowledge and tactics to deal with risks in everyday life.

It is confirmed in this study that crime is a major constraint on the local behavior and activities of women (Pain 1997: 243). Some of the lines are within the border and outside of neighborhood; within crowded and isolated places and between day and night. Thus, as stressed by feminist geographer Gill Valentine, women's fear seems to be a "spatial expression of patriarchy." Women's mobility in the urban space is directly affected by that.

Temporal and local "experience" is transferred from mothers to daughters. In some cases, though they are not very keen mothers find themselves intervening on their daughters' dressing styles when going out of neighborhood, going out at night or spending the night together with a male friend. Such interventions turn to be restrictions and accept as obedience by the daughters. Thus, mother-daughter interactions do not diminish fear work of women based on the division of fear work as it does in couple interactions (Rader 2009) but it generates a more oppressive mechanism for women.

As a policy recommendation; education on gender, transformation of traditional values based on honor into human rights and gender equality would contribute elimination of oppression through fear of crime.

\section{References}

Day K (1994) Conceptualizing women's fear of sexual assault on campus: A review of causes and recommendations for change. Environment and Behavior 26(6): 742-765.

Ferraro KF (1996) Women's fear of victimization: Shadow of sexual assault? Social Forces: 667-690.

Fisher BS, Sloan III JJ (2003) Unraveling the fear of victimization among college women: Is the "shadow of sexual assault hypothesis" supported? Justice Quarterly 20(3): 633-659.

Gardner CB (1990) Safe conduct: women, crime, and self in public places. Social Problems 37(3): 311-328.

Hollander JA (2001) Vulnerability and dangerousness: The construction of gender through conversation about violence. Gender and Society 15(1): 83-109.

Kagitcibasi C (1970) Social norms and authoritarianism: A Turkish-American comparison. Journal of Personality and Social Psychology 16(3): 444.

Kandiyoti D (2010) Ataerkil örüntüler: Türk toplumunda erkke egemenliğinin 
çözümlenmesine yönelik notlar [Patriarchal patterns: Notes on the analysis of male dominance in Turkish society]. In 1980'ler Türkiye'sinde Kadın Baklş Açısından Kadınlar (içinde), ed. Şirin Tekeli, 327-340.

Kandiyoti (1991) Islam and Patriarchy: A Comparative Perspective. In Women in Middle Eastern History, NR Keddie, B. Baron (eds), 23-42. Yale University Press.

Madriz EI (1997) Images of criminals and victims: A study on women's fear and social control. Gender and Society 11(3): 342-356.

May DC (2001) The effect of fear of sexual victimization on adolescent fear of crime. Sociological Spectrum 21(2): 141-174.

Pain RH (1997) Social geographies of women's fear of crime. Transactions of the Institute of British Geographers 22(2): 231-244.

Rader N (2009) Until death do us part? Husband perceptions and responses to fear of crime. Deviant Behavior 31(1), 33-59.

Rader N, Haynes SH (2011) Gendered fear of crime socialization: An extention of Akers's social learning theory. Feminist Criminology 6(4), 291-307.

Stanko EA (1996) Warnings to women: Police advice and women's safety in Britain. Violence against Women 2(1), 5-24.

Stanko E (1995) Women, crime and fear. The Annals of the American Academy of Political and Social Science 539(1), 46-58.

Valentine G (1989) The geography of women's fear. Area, 385-390.

Van Eijk G (2017) Between risk and resistance: gender socialization, equity, ambiguous norms in fear of crime and safekeeping. Feminist Criminology, 1-22.

Warr M (1984) Fear of victimization: Why are women and the elderly more afraid? Social Science Quarterly 65(3): 681.

Wilcox P, Jordan CE, Pritchard AJ (2006) Fear of acquaintance versus stranger rape as a "master status": Towards reinforcement of the shadow of sexual assault. Violence and Victims 21(3): 355-370. 
